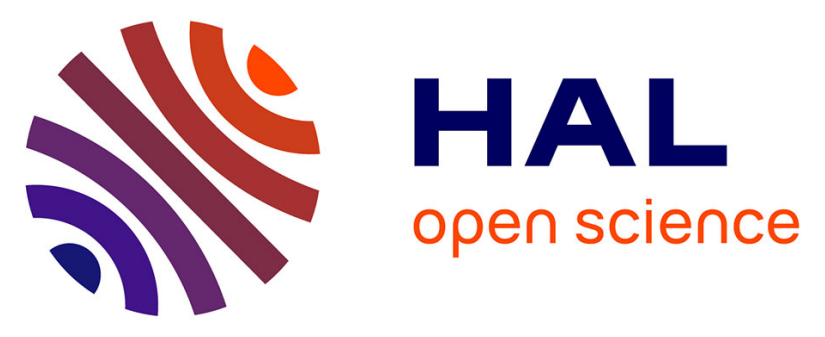

\title{
Early to mid-Holocene climate change at Lago dell'Accesa (central Italy): climate signal or anthropogenic bias?
}

Walter Finsinger, Danièle Colombaroli, Jacques-Louis de Beaulieu, Verushka Valsecchi, Boris Vannière, Elisa Vescovi, Emmanuel Chapron, André F. Lotter, Michel Magny, Willy Tinner

\section{To cite this version:}

Walter Finsinger, Danièle Colombaroli, Jacques-Louis de Beaulieu, Verushka Valsecchi, Boris Vannière, et al.. Early to mid-Holocene climate change at Lago dell'Accesa (central Italy): climate signal or anthropogenic bias?. Journal of Quaternary Science, 2010, 25 (8), pp.1239-1247. 10.1002/jqs.1402 . insu-00592200

\section{HAL Id: insu-00592200 \\ https://hal-insu.archives-ouvertes.fr/insu-00592200}

Submitted on 12 Oct 2011

HAL is a multi-disciplinary open access archive for the deposit and dissemination of scientific research documents, whether they are published or not. The documents may come from teaching and research institutions in France or abroad, or from public or private research centers.
L'archive ouverte pluridisciplinaire HAL, est destinée au dépôt et à la diffusion de documents scientifiques de niveau recherche, publiés ou non, émanant des établissements d'enseignement et de recherche français ou étrangers, des laboratoires publics ou privés. 


\section{Early to mid-Holocene climate change at Lago dell'Accesa (central Italy): climate signal or anthropogenic bias? ${ }^{\dagger}$}

1. Walter Finsinger ${ }^{1,2,3,{ }^{*}}$, Daniele Colombaroli ${ }^{1,4}$, Jacques-Louis De Beaulieu $^{5}$, Verushka Valsecchi ${ }^{1,2,3}$, Boris Vannière ${ }^{6}$,

2. Elisa Vescovi ${ }^{1}$, Emmanuel Chapron ${ }^{7}$, André F. Lotter ${ }^{2}$, Michel Magny ${ }^{6}$, Willy Tinner ${ }^{1,8}$

Keywords: pollen; transfer functions; lake-level changes; temperature; precipitation; Holocene; Mediterranean; human impact

\section{Abstract}

Despite the high potential of pollen records for climate reconstruction, pollen-climate relationships may be biased due to past and present human activities on the landscape. We use (i) transfer functions based on modern pollen-climate relationships to infer seasonal temperature and summer precipitation for the period 11 500-4500 cal. a BP and (ii) lake-level change records based on different sedimentary proxies in multiple cores that are mainly indicative for summer hydrology at Lago dell'Accesa (central Italy). Quantitative reconstructions indicate lowest summer precipitation during two phases (8500-7700 cal. a BP and after $6000 \mathrm{cal}$. a BP) and a gradual winter temperature increase from 11500 to ca. 8000 cal. a BP. Lowest summer precipitation was reconstructed during these phases characterised by vegetation shifts from open forests dominated by summergreen oaks (Quercus) to forests dominated by evergreen oaks (Quercus ilex), which are at present most abundant where summer drought is stronger. Similarly, the lake-level record indicates two long-lasting low summer precipitation phases (8800-7700 and 6400-4400 cal. a BP) that were interrupted by short-term high summer precipitation events. Based on the broad agreement between the pollen-inferred summer precipitation and the low-frequency lake-level changes, we suggest that the duration of the high summer precipitation events may have been too short to maintain drought-sensitive trees, which may have been affected by high mortality rates when summer dry conditions returned. Although past and modern pollen-climate relationships may very likely have been affected by human activities since the Neolithic (i.e. when exploitation of the landscape started), we reject the hypothesis of a significant anthropogenic bias in the pollen-based climate reconstruction. In addition, we suggest that pollenbased and lake-level reconstructions may have different inherent abilities of capturing high- and low-frequency precipitation signals.

\section{Introduction}

The understanding of long-term climate dynamics requires quantitative records of past climates that exceed the timescales of the available instrumental and documentary records. Quantitative reconstructions of temperature and precipitation based on pollen assemblages are widely available (e.g. Bartlein et al., 1984; Huntley and Prentice, 1988; Guiot et al., 1993; Lotter et al., 2000; Seppä and Birks, 2001) and have been used to reconstruct climate change over large spatial scales (e.g. Peyron et al., 1998; Davis et al., 2003) or to compare reconstructions with GCM (General Circulation Model) outputs (e.g. Diffenbaugh and Sloan, 2004; Wiersma and Renssen, 2006; Allen et al., 2008; Donders et al., 2010). Often such reconstructions are based on a single 
palaeoclimatic proxy (i.e. pollen) or focus on specific climatic variables, usually temperature. However, in order to provide a more coherent picture of past climate dynamics, it may be necessary to use a combination of proxy records to cross-validate climate reconstructions and to reconstruct different components of the climate system (e.g. Giesecke et al., 2008). In addition, one major concern when using pollen records to reconstruct past climates is that the past and the present-day pollen-climate relationships may be affected by factors other than climate, for example by human activities (Howe and Webb, 1983; Birks and Seppä, 2004; Jacques et al., 2008). While this may only be a minor problem for calibrating pollen-climate relationships and for reconstructing Holocene climate changes in regions that were not significantly affected by human disturbance (Seppä and Bennett, 2003), such as in Fennoscandia (e.g. Seppä and Birks, 2001) or North America (e.g. Jacques et al., 2008), it might be an important factor for the Mediterranean region, where intense human activities such as deforestation, man-made forest fires and agriculture started several millennia ago (Roberts, 1998). Although this is a largely ignored problem in pollen-climate inference models (for discussion see Seppä and Bennett, 2003; Birks and Seppä, 2004), reconstructions based solely on modern pollen-climate relationships from the Neolithic onwards should be interpreted with caution.

Several vegetation-independent palaeoclimate reconstructions suggest marked changes in the water balance on the borderlands of the Mediterranean Sea (Reed et al., 2001; Digerfeldt et al., 2007; Zanchetta et al., 2007; Finsinger et al., 2008; Roberts et al., 2008; Magny et al., 2009). Among the many factors influencing changes in vegetation, summer precipitation $\left(P_{\mathrm{smr}}\right)$ was very likely a dominant and ecologically meaningful climatic parameter for biome changes at low altitude in the Mediterranean region (e.g. Magny et al., 2007a; Tzedakis, 2007; Colombaroli et al., 2009; Noti et al., 2009; Tinner et al., 2009). Here we focus on the cross-validation of palaeoclimate reconstructions at Lago dell'Accesa, a lake located at low altitude in central Italy. Seasonal temperatures and precipitation were reconstructed based on modern pollen-climate relationships for the early to mid Holocene (ca. 11 650-4500 cal. a BP). The pollen-based climate reconstructions were then compared to two high-resolution records of lake-level change at Lago dell'Accesa: (i) the 'synthesis lake-level change record' that was compiled based on multiple evidence from four sediment cores taken along a transect perpendicular to the lakeshore (Magny et al., 2007a); and (ii) the lake-level change record from only one of these sediment cores (AC3/4), which offered the highest temporal resolution (Magny et al., 2006) and which highlights the lowfrequency (millennial-scale) trends. These lake-level records are assumed to be mainly indicative for changes in summer hydrology because the reconstruction is based on the abundance of macroscopic carbonate concretions that are formed during the summer season (Magny, 1998).

This period includes the late Palaeolithic and Mesolithic period (11 650-8000 cal. a BP), when human impact on the landscape is assumed to be minor or negligible compared to the period from the Neolithic onwards. Hence our approach may be useful to observe potential biases in pollen-based reconstructions, considering human impact to be present already since the onset of the Neolithic (ca. 8000 cal. a BP; Malone, 2003; Turney and Brown, 2007), when agricultural activities and exploitation of the landscape started in the region (Bellini et al., 2008). 


\section{Material and methods}

\section{Site description and previous studies}

Lago dell'Accesa $\left(42^{\circ} 59.33^{\prime} \mathrm{N}, 10^{\circ} 53.83^{\prime} \mathrm{E} ; 157 \mathrm{~m}\right.$ above sea level; Fig. 1) is a karstic lake (surface: $0.16 \mathrm{~km}^{2}$ ) surrounded by hills up to $300 \mathrm{~m}$ high. In summer 2005, when the seismic survey was made (Fig. 1), the lake had a maximum water depth of $37.5 \mathrm{~m}$. The modern lake level is slightly lower than the maximum natural lake level because a small trench ( $\sim .5 \mathrm{~m}$ deep) was built to drain the lake at the outlet (Magny et al., 2007a). The regional climate is Mediterranean, with a mean annual precipitation of $\sim 700 \mathrm{~mm}$ which is lowest in summer $(\sim 100 \mathrm{~mm})$ and highest in winter $(\sim 190 \mathrm{~mm})$ and autumn $(\sim 250 \mathrm{~mm})$. Mean annual temperature is $15^{\circ} \mathrm{C}$, and the mean July and January temperatures are 24 and $7^{\circ} \mathrm{C}$, respectively (Finsinger et al., 2007).

Sediments of Lago dell'Accesa have been intensively studied in the framework of multi-proxy and multi-archive palaeoecological investigations including pollen, microscopic charcoal and sedimentological analyses from lake and peat deposits (Magny et al., 2006, 2007a, $\underline{\text { b; }}$ Drescher-Schneider et al., 2007; Colombaroli et al., 2008, 2009; Vannière et al., 2008). At the coring site AC05 (lake centre, $35 \mathrm{~m}$ water depth in summer 2006, Fig. 1), where sediments consisted of light-brown to dark-grey silty gyttja (Matter, 2005; Vannière et al., 2008), pollen analyses were carried out (Colombaroli et al., 2008).

\section{Pollen-inferred climate}

January and July mean temperature ( $T_{\mathrm{Jan}}$ and $\left.T_{\mathrm{Jul}}\right)$, as well as mean summer and winter precipitation $\left(P_{\mathrm{smr}}\right.$ and $\left.P_{\text {win }}\right)$, were reconstructed using weighted averaging partial least squares (WA-PLS) inference models as implemented by the program $\mathrm{C}^{2}$ v. 1.5 .1 (Juggins, 2003). The reconstructions are based on the entire pollen dataset of a modern training set of 79 surface samples from the Italian Peninsula (Finsinger et al., 2007). Interestingly, the model performed well in cross-validation tests with modern climate observations, despite a history of long-term human impact that disrupted the natural vegetation. All pollen percentage values were square-root transformed before applying inference models. Because the amplitude of centennial-scale changes is smaller than the uncertainties of the reconstructions (estimated standard errors of prediction (eSEP)), major multi-centennial trends were extracted by smoothing the reconstruction using a loess function (locally weighted regression; Cleveland and Devlin, 1988). Directional changes of pollen assemblages through time were assessed by passively including fossil pollen samples in a canonical correspondence analysis (CCA) of the modern pollen and climate data (e.g. Bigler et al., 2002; Larocque and Finsinger, 2008). In addition, reliability of inferences was assessed following Birks et al. (1990) by using two criteria: (1) goodness-of-fit to an environmental variable; and (2) analogue measures. Goodness-of-fit was estimated using the squared-residual distances of modern samples to the first CCA axis that was constrained to the environmental variable of interest. Fossil samples with residual distance equal to or larger than the residual distance of the extreme $5 \%$ of the modern training set samples were considered to have a 'very poor' fit to the environmental variable. To identify fossil pollen assemblages with poor modern analogues in the modern training set we used chi-square distance $\left(X^{2}\right)$ and squared-chord distance (SCD) as dissimilarity coefficients (Prentice, 1980; Overpeck et al., 1985). Fossil samples with a minimum $X^{2}$ greater than the extreme $5 \%$ of the $X^{2}$ distribution for comparison between all the modern calibration samples were considered to have no 'good' modern analogue. All CCAs were carried out with CANOCO v. 4.5 (ter Braak and Smilauer, 
2003) and dissimilarity coefficients were assessed using $C^{2}$. Time series of lake-level change and pollen-inferred climate reconstructions were interpolated to the same sampling density (here $15 \mathrm{a}$ ) and thereafter smoothed with a loess function (Cleveland and Devlin, $\underline{1988}$ ) with a ca. 700 a smoothing window.

\section{Lake-level change reconstruction}

The reconstruction of Holocene lake-level fluctuations at Lago dell'Accesa (Magny et al., 2007a) relies on the comparative sediment analysis of four sediment cores (AC3/4, AC5, AC6 and AC7) taken along a transect perpendicular to the lakeshore (Fig. 1). Core AC1/2 was not analysed because it presented similar lithological changes to the AC3/4 cores. The analysis combines several markers, including sediment lithology, grain size and the abundance of macroscopic carbonaceous components (Magny, 1998, 2006). Analyses of surface samples in carbonate lakes (Magny, 1998, 2006) have shown that peat deposits correspond to overgrowing processes (shore area), whereas lake marls accumulate at lower water depths. In particular, oncolites and tufa concretions dominate from 0 to $\sim 1 \mathrm{~m}$ water depth; high abundance of tube-like concretions develops in association with the Characeae belt at the extremity of the littoral platform, i.e. at $\sim 4-5 \mathrm{~m}$ water depth in the case of Lago dell'Accesa (Magny et al., 2007a).

The analysis of four cores along the transect perpendicular to the shore allowed for the reconstruction of the geometry of the layers. It also permits (1) detection of sediment hiatuses (geometric unconformities) resulting from erosion or non-deposition (lake-level lowering) and (2) observation of lateral variations in the sediment facies informative for the reconstruction of water depth in the past deposition environments. For each individual core, a relative lake-level change record ('dimensionless') has been subsequently reconstructed based on the ratio between indicators of lower vs. higher lake-level conditions. The synthesis lake-level change record ('quantitative', in metres with modern lake level set at zero) has been established based on the evidence of relative fluctuations in all individual cores.

\section{Chronologies}

The chronology of core AC05 is based on a depth-age model (described by Vannière et al., 2008) that was developed using 12 accelerator mass spectrometry (AMS) ${ }^{14} \mathrm{C}$ dates measured on terrestrial plant macrofossils (wood, bud scales, leaves and charcoal). Uncertainties in the age estimates of the model comprise, on average, ca. \pm 390 a $(2 \sigma)$ for the sediment section used in this study.

The chronology for the lake-level change record is based on $43 \mathrm{AMS}{ }^{14} \mathrm{C}$ dates measured on wood or on peat from the four sediment cores (AC3/4, AC5, AC6 and AC7) and on four Holocene tephra layers identified in cores AC3/4 (Magny et al., 2007a). Depth-age models for the individual cores were developed using mostly a linear interpolation between calibrated ages within the $1 \sigma$ band of the calibration uncertainties (Magny et al., 2006). Stratigraphic correlations between the sediment profiles of cores AC3/4, AC5, AC6 and AC7 were established based on (i) the calendar ages of calibrated radiocarbon dates and of tephra layers, and (ii) changes in the lithology and the sediment composition as highlighted by sediment analysis. Although no explicit uncertainties in the age estimates for the lake-level change record are available, we can approximate them to be at least as large as the mean $2 \sigma$ range width of calibrated ${ }^{14} \mathrm{C}$ dates (ca. \pm 130 a). 


\section{Results}

\section{Pollen-inferred vegetation dynamics}

At Lago dell'Accesa, early Holocene pollen assemblages (11 500-10 700 cal. a BP) were dominated by Pinus and summergreen Quercus, with high abundances of grass pollen (Fig. 2), indicating a parkland landscape (Ac05-1). This gradually changed around 10700 cal. a BP into a summergreen Quercus-dominated woodland, with small amounts of Abies, Corylus, Fraxinus and Erica-type shrubs until 8500 cal. a BP (Ac05-2), though open land continued to decrease gradually, as suggested by increasing arboreal pollen until ca. 8000 cal. a BP. Two distinct expansion phases of Quercus ilex (evergreen oak) occurred: (i) from 8500 to 7700 cal. a BP; and (ii) from 6000 to 5500 cal. a BP (Ac05-3 and Ac05-5). These two phases were separated by a period with a more open landscape, as inferred from higher abundance of herb and shrub pollen (e.g. Poaceae and Erica arborea), and with dominance of summergreen Quercus (Ac05-4). Scattered grains of pollen indicative of agriculture (Secale and Cerealia-type) indicate that farming activities occurred in the vicinities of the lake after ca. 7300 cal. a BP. Hence, if the opening of the forests at $\sim 7700$ cal. a BP was caused by human activities, then earliest signs of human impact on vegetation started slightly earlier than the first occurrence of pollen indicative of agriculture.

\section{Pollen-based climate reconstructions}

$T_{\text {Jul }}$ rapidly increased during the early Holocene from $\sim 19^{\circ}$ to $\sim 21^{\circ} \mathrm{C}$, levelled off between 10000 and $6400 \mathrm{cal}$. a $\mathrm{BP}$ and thereafter increased to $\sim 22^{\circ} \mathrm{C}$ (Fig. ). Although $T_{\text {Jan }}$ broadly parallels the $T_{\text {Jul }}$ main trends, it reached a first local maximum $\left(\sim 5^{\circ} \mathrm{C}\right)$ at ca. $8500-8000$ cal. a BP, then levelled off to slightly lower values $\left(\sim 3.5^{\circ} \mathrm{C}\right)$ between 7500 and 6500 cal. a BP and increased, reaching a second local maximum $\left(\sim 6^{\circ} \mathrm{C}\right)$ between 6000 and $5500 \mathrm{cal}$. a BP. $P_{\text {win }}$ increased between 11000 and 10000 cal. a BP, levelled off until 9000 cal. a BP and subsequently increased again during two phases dated to $9000-7600$ and $6000-4500$ cal. a BP. In contrast to the increases of $T_{\text {Jul }}, T_{\text {Jan }}$ and $P_{\text {win }}$ during the early Holocene, $P_{\text {smr }}$ remained stable between 11500 and 9000 cal. a BP. $P_{\text {smr }}$ subsequently decreased during two phases dated to $8800-7700$ cal. a BP and $6300-4500$ cal. a BP.

\section{Discussion}

Given the importance of human activities in shaping modern European landscapes and vegetation, it is unlikely that all the taxa in all parts of Europe in modern pollen assemblages are systematically related to modern climate (Seppä and Bennett, 2003; Birks and Seppä, 2004). Hence quantitative reconstructions of climate variables using modern pollen-climate calibration sets should be interpreted cautiously because the datasets may contain an anthropogenic bias, distorting the climate signal (Howe and Webb, 1983). Critical evaluation of such reconstructions may thus be essential (Birks and Seppä, 2004), especially in regions such as the Mediterranean, where vegetation may have been altered due to agriculture, deforestation and man-made fires for millennia (Roberts, 1998; Colombaroli et al., 2008). We use here two independent lines of evidence for evaluating the pollen-inferred climate reconstruction: indirectly, using numerical criteria as outlined by Birks (1990, 1998), and directly, by using independent palaeoenvironmental data. 


\section{Evaluation of the reconstruction}

Few samples of Lago dell'Accesa fall outside the modern environmental space covered by the training set (Fig. $\underline{4}(\mathrm{~A}))$. This confirms that all fossil samples have 'close modern analogues' in the modern training set. Closest modern analogues in the calibration set (min.-max. $X^{2}$ distance: 25-37) were well below the $X^{2}$ distance of 50 used as a cut-off level to identify samples with no 'good' analogue in the calibration dataset. One possible reason for the relative similarity of modern and fossil pollen assemblages may be the large gradient covered by the training set, which spans from subalpine vegetation in the Alps to the evergreen, partly sclerophyllous Mediterranean vegetation in southern Italy. The climatic space covered by the modern training set is larger than the one covered by the fossil samples (Fig. $\underline{4}(\mathrm{~A})$ ). As a result, pollen assemblages in the modern training set are very dissimilar among each other and the cut-off level to identify samples with no 'good' analogues as defined here is therefore high. A factor certainly influencing the dissimilarity is very likely the absence (or low abundance) of pollen types produced by exotic plants (e.g. Eucalyptus) or by cultivated plants (e.g. Cerealia-type, Secale, Castanea, Juglans) in the fossil pollen assemblages. In addition, we cannot a priori exclude that the unique climate conditions during the early Holocene, when insolation was high in summer and low in winter (COHMAP Members, 1988; Berger and Loutre, 1991), may have created environmental conditions for plant communities that lack modern analogues (Jackson and Overpeck, 2000). For instance, high summer and low winter insolation during the early Holocene may have substantially influenced vegetation composition and dynamics in Europe (Huntley, 1993; Finsinger et al., 2006).

The pollen record of Lago dell'Accesa suggests open natural habitats during the period between 11500 and 10 000 cal. a BP (Fig. 2). Pre-Neolithic human impact on vegetation was very likely negligible if compared to the extent of human activities during the Neolithic or at the present day (Roberts, 1998). Nevertheless, early Holocene pollen assemblages have substantially shorter distances to their closest modern analogues than the pollen assemblages deposited after $8000 \mathrm{cal}$. a BP, which may suggest that the early Holocene landscape was possibly similar to the present-day landscape in the vicinities of the closest modern analogues. This is striking because it indicates that among the fossil pollen assemblages those resembling the modern assemblages most closely were deposited when human activities were negligible. A reason for this might be that, at Lago dell'Accesa, early Holocene landscapes were more open than during the mid Holocene: pollen of Poaceae, Rumex and Plantago lanceolata were more abundant during the early Holocene than after $10000 \mathrm{cal}$. a BP (Fig. 2). High abundance of Pinus and summergreen Quercus pollen suggest a pine and summergreen Quercus (probably Q. pubescens; Drescher-Schneider et al., 2007) dominated woodland. While the main cause for modern open landscapes is unambiguously identified with human activities (e.g. Verburg et al., 2008), natural high fire frequencies and dry climate conditions during the early Holocene may have contributed to keep the landscape open in southern Europe (Finsinger et al., 2006; Vannière et al., 2008).

The relatively higher dissimilarity coefficients of mid-Holocene pollen assemblages suggest that land use activities during the Neolithic possibly lack such close analogues in our modern pollen assemblages as the early Holocene assemblages. High-resolution charcoal and pollen records from Tuscany, Sicily and Croatia (Colombaroli et al., $\underline{2009}$ ) indicate that charcoal-inferred fire activity was high when Q. ilex abundance was low (at Lago dell'Accesa 
between 7700 and $6000 \mathrm{cal}$. a BP) and vice versa. This suggests that higher fire incidence affected the forest composition, converting broadleaf evergreen forests to open landscapes with patches of summergreen Quercus forests and shrubby Ericaceae communities (Colombaroli et al., 2009). The pollen record at Lago dell'Accesa undoubtedly shows that agricultural activities started at the latest by $7300 \mathrm{cal}$. a BP (first record of Secale and Cerealia-type pollen; Fig. 2), which is in agreement with the onset of the Neolithic period in this region (dated to ca. 8000 cal. a BP; see Malone, 2003). Thus it is likely that at least some forest fires were set by Neolithic farmers. However, according to pollen of crops and weeds, human impact on vegetation remained irregular and/or relatively low until $4500 \mathrm{cal}$. a BP, when most anthropogenic indicators began to be recorded as continuous curves and reached higher values than before (Drescher-Schneider et al., 2007; Magny et al., 2007a; Colombaroli et al., 2008). Based on the dissimilarity coefficients between fossil and modern pollen assemblages (Fig. $\underline{4}(\mathrm{~B})$ ), we may infer that human activities during the Neolithic had a weaker influence on landscape openness than natural factors prior to ca. $10000 \mathrm{cal}$. a BP. In fact, in our training set the presence of Ericaceae pollen in modern assemblages is very rare and Poaceae pollen is abundant across the entire climate gradient (Finsinger et al., 2007), suggesting that such extensive shrubby Ericaceous communities as can be inferred from the pollen record of Lago dell'Accesa during the Neolithic are not common in modern landscapes. Nevertheless, several Ericaceae shrubs (e.g. Erica arborea) are at present abundant in the summer-dry lowland landscapes in the Mediterranean, so that human impact might possibly be confused with summer-dry conditions and vice versa.

Most samples show a 'very poor' fit with environmental variables if added passively into a CCA with one variable at the time as the only predictor (percentage of samples with 'very poor' goodness-of-fit for individual climatic variables: $\left.P_{\mathrm{smr}} 87.3 \% ; T_{\mathrm{Jul}} 80.9 \% ; T_{\mathrm{Jan}} 85.7 \% ; P_{\text {win }} 79.4 \%\right)$. We interpret this as an indication that changes in the fossil dataset are not related to changes of one climatic variable alone. In fact, taxonomic composition and relative abundances of biotic communities are often influenced by a complex combination and interaction of several environmental variables, which may be correlated with each other. The reduction of such complex interactions to a single (or few) environmental variable(s) from changes in fossil assemblage compositions involves considerable simplification (Birks, 2004). At present, several climatic variables are closely correlated spatially on the Italian

Peninsula ( $T_{\text {Jul }}, T_{\text {Jan }}$ and $P_{\text {win }}$; Fig. 4) and can possibly not be used independently (Finsinger et al., 2006). Maxima in $T_{\mathrm{Jan}}$ and minima in $P_{\mathrm{smr}}$ coincide with phases of maximal abundance of $Q$. ilex (Fig. $\underline{3}$ ), which has a present-day distribution centred in regions with hot/dry summers and wet/mild winters (Pignatti, 1997). In the Mediterranean, summergreen plants are at a disadvantage in comparison to evergreens because the period of physiological activity for the summergreen plants coincides with the most unfavourable season (summer) with regard to water availability (Givnish, 2002). In addition to $P_{\mathrm{smr}}$, minimum and maximum temperatures can also play a role if plants have a low tolerance to absolute or cumulative low temperatures (winter) or if gross primary production does not exceed (summer) respiration (Box and Fujiwara, 2005). Based on these considerations, we retained $T_{\mathrm{Jan}}$ and $P_{\mathrm{smr}}$ as the ecologically most meaningful environmental variables for pollen-based climate reconstructions at Lago dell'Accesa.

\section{Validation with lake-level change records}


We use smoothed lake-level change records (Fig. $\underline{5}$ (A, B) developed for Lago dell'Accesa (Magny et al., 2007a) as independent estimates for summer moisture availability against which to compare the smoothed pollen-based $P_{\text {smr }}$ reconstruction (Fig. $\underline{5}(\mathrm{C})$ ). The two lake-level records were obtained (i) by summarising lake-level changes in multiple cores along a transect perpendicular to the lake shore (Lago dell'Accesa lake-level record; Fig. $\underline{5}(A))$ and (ii) using proxy evidence from two cores collected at the base of that transect (AC3/4; Fig. $\underline{5}(B))$. The lake-level and pollen records probably have different spatial resolutions. Surely the lake-level depends on precipitation in the hydrological catchment $\left(\sim 5 \mathrm{~km}^{2}\right)$. By contrast, as suggested by empirical and simulation studies, for a medium-size lake such as Lago dell'Accesa (surface area $\sim 16 \mathrm{ha}$ ), the relevant pollen source area may be within a radius of a few kilometres at most (Sugita, 1994; Sugita et al., 1999), whereas the total pollen source area may be regional (i.e. $<10-50 \mathrm{~km}^{2}$; Jacobson and Bradshaw, 1981). However, the lake is located in a homogeneous hilly landscape without particular changes in topography or climatic conditions over a distance of $\sim 20 \mathrm{~km}$. It is thus likely that vegetation changes were homogeneous in that area for reasons other than human activities. Thus we expect that the two records yield a coherent pattern of changes in summer hydrological conditions.

Reconstructed lake levels were lower than today during the period 11 500-4500 cal. a BP at Lago dell'Accesa (Fig. $\underline{5}(A)$ ). This suggests that moisture availability was considerably lower than today, pointing to conditions substantially drier than today during the early and mid Holocene (Magny et al., 2007a). These drier conditions could explain the persistence of open parklands and high fire activity at Lago dell'Accesa during the early Holocene (Colombaroli et al., 2008; Vannière et al., 2008). In contrast, reconstructed mean pollen-inferred $P_{\text {smr }}$ is not lower than today (Fig. $\underline{3}(\mathrm{~b})$ ). However, since the reconstructed $P_{\mathrm{smr}}$ (with its prediction errors) is within the modern $P_{\mathrm{smr}}$ range $(100 \mathrm{~mm})$, there is no evidence to reject the reconstruction. In addition, such differences between lake-level and pollen-inferred precipitation reconstructions might be attributed to the lower resolution of the precipitation reconstructions as compared to those of temperature. Support for this view comes from numerous quantitative pollen-based climate reconstructions that have identified higher error margins for precipitation-related than for temperature-related parameters (e.g. Guiot et al., 1993; Finsinger et al., 2007). Finally, given the affinity of pollen signals deriving from summer-dry conditions and human impact (or early Holocene and modern pollen assemblages), it is conceivable that our transfer functions may overestimate the absolute amounts of precipitation during the period where human impact was negligible (i.e. before 7500 cal. a $\mathrm{BP})$.

The Lago dell'Accesa lake-level record (Fig. $\underline{5}(\mathrm{~A})$ ) and $P_{\text {smr }}$ reconstruction (Fig. $\underline{5}(\mathrm{C})$ ) both indicate that, when limiting the view to the period prior to $4500 \mathrm{cal}$. a BP, summer moisture availability was at its highest during the early Holocene (11 500-9300 cal. a BP). Low lake levels and low $P_{\text {smr }}$ are found between 8800 and 7700 cal. a BP. However, the Lago dell'Accesa lake-level record and $P_{\mathrm{smr}}$ reconstruction clearly diverge after $7000 \mathrm{cal}$. a BP, when $P_{\text {smr }}$ shows a period of high values (7700-6200 cal. a BP), followed by a strong decrease after $6200 \mathrm{cal}$. a $\mathrm{BP}$, while the lake-level record indicates a shorter lake-level maximum (7700-7000 cal. a BP), followed by a period with less extreme low lake levels.

We suggest that the duration of high and low lake-level events may explain the apparent discrepancy between the two records after $7000 \mathrm{cal}$. a BP. In fact, the $P_{\mathrm{smr}}$ maximum at $7700-6000 \mathrm{cal}$. a BP has a counterpart in the 
AC3/4 record (Fig. $\underline{5}(B)$ ), which shows a long-lasting high lake level at $7700-6400$ cal. a BP. Furthermore, the second $P_{\text {smr }}$ minimum broadly coincides with a period characterised by the domination of low lake-level conditions (6400-4400 cal. a BP) at the AC3/4 site (Magny et al., 2007a). This low stand, which allowed the accumulation of an increasing thickness of a peat layer in the AC3/4 site, was interrupted by five short-term high lake-level stands that were responsible for the deposition of lake marl in the more distal sites AC5 and/or AC6 (Fig. 1; Magny et al., 2007a). Thus the apparent discrepancy between the Lago dell'Accesa lake-level record and the $P_{\text {smr }}$ records may be reconciled assuming that the short-term wetter phases between 6400 and $4400 \mathrm{cal}$. a BP had too short a duration to affect the vegetation significantly. Our interpretation is in agreement with evidence showing that increased mortality of woody vegetation due to water stress can be rapid $(<5 \mathrm{a})$ and can have a persistent effect on vegetation (Allen and Breshears, $\underline{1998}$ ). Strikingly, it seems that wet multi-decadal climate oscillations may increase plant susceptibility to drought-induced mortality by stimulating shifts in hydraulic architecture (e.g. increased leaf area and reduced growth of roots and sapwood), effectively predisposing plants to water stress (McDowell et al., 2008). Although we cannot be certain that this mechanism also applied to plants present at Lago dell'Accesa during the early to mid Holocene, it constitutes a hypothesis that deserves investigation.

The two records diverge in terms of timing and rapidity of changes. While the lake-level change curve indicates earlier onsets of abrupt and high-amplitude decreases, more gradual changes of $P_{\text {smr }}$ reaching minimal values were reconstructed by pollen data. The absence of a rapid $P_{\mathrm{smr}}$ decrease is striking because drought-induced vegetation changes should be rapid and the lake-level change record undoubtedly points to a multi-century long dry period. Two possible mechanisms acting on the vegetation might explain the difference between the two reconstructions. On the one hand, the lake-level inferred decrease in summer moisture availability did possibly not cross an ecological threshold that could have induced a rapid vegetation shift from summergreen to evergreen broadleaf vegetation (Tzedakis et al., 2004). On the other hand, it is well known that vegetation is also influenced by factors other than summer drought such as late frost, winter temperature, and seasonality (Box and Fujiwara, $\underline{2005}$ ). It has been argued that low winter temperatures, caused by early Holocene minimum winter insolation in the Northern Hemisphere, were a limiting factor for the population and range expansions of evergreen broadleaf forests in central and northern Italy (Finsinger et al., 2006). The $T_{\text {Jan }}$ record is consistent with a continent-wide pollen-based temperature reconstruction for Europe indicating a $2^{\circ} \mathrm{C}$ winter temperature increase between 11000 and 6000 cal. a BP (Davis et al., 2003). Although the shorter lag (ca. 300 a) between the lake-level lowering and the $P_{\text {smr }}$ decrease at $6400 \mathrm{cal}$. a BP may also be caused by dating uncertainties in the two sediment cores (i.e. the AC05 centre lake core and the AC3/4 core on the lake shore; Fig. 1), it is consistent with the concept of a dynamic equilibrium (nonlinear responses with response lags) between vegetation and climate conditions due to intrinsic biological factors (Webb, 1986; Prentice et al., 1991).

The comparison between the pollen-based $P_{\mathrm{smr}}$ reconstruction and the lake-level records at Lago dell'Accesa suggests that human activities prior to 4500 cal. a BP played an insignificant role for past vegetation-climate relationships because the $P_{\text {smr }}$ reconstruction does not contradict the independent low-frequency lake-level record. Hence, although human activities (e.g. deforestation, irrigation, cultivation, planting of new species) may be a confounding factor of pollen-based climate reconstructions (for discussions see Howe and Webb, 1983; Birks and 
Seppä, 2004; Jacques et al., 2008), we can reject the hypothesis of a significant anthropogenic bias in the pollenbased climate reconstruction at Lago dell'Accesa for the early to mid Holocene. Our results may not be extendable to other early to mid-Holocene pollen records from southern Europe. In fact, it is conceivable that human activities were more intensive in other parts of the Mediterranean during the mid Holocene and that therefore the potential anthropogenic bias in pollen-based climate reconstructions may be stronger. This study also suggests the powerful help offered by a multi-proxy strategy for the interpretation of palaeoecological records in terms of past climate changes and for the evaluation of possible interferences of human impact on climate reconstruction.

\section{Conclusions}

The Lago dell'Accesa pollen record provides centennial-scale quantitative estimates of rainfall and temperature during the early to mid Holocene for central Italy. The smoothed pollen-based climate reconstructions indicate that $P_{\text {smr }}$ was highest during the early Holocene (11 500-9000 cal. a BP) and decreased between ca. 8800 and 7800 cal. a BP as well as between 6200 and 4500 cal. a BP. In contrast, $T_{\text {Jan }}$ gradually increased over the period 11 500-8000 cal. a BP and increased again at ca. 6000 cal. a BP. Pollen inference models reconstructed these changes because vegetation composition shifted from vegetation dominated by summergreen Quercus (abundant today in summer-moist regions) to landscape dominated by evergreen $Q$. ilex forests (abundant today in summerdry regions). To test whether early to mid-Holocene vegetation changes at Lago dell'Accesa may have been influenced by human activities (agriculture, deforestation, forest fires) during the Neolithic (8000-4500 cal. a BP), pollen-based reconstructions of $P_{\mathrm{smr}}$ were compared to independent lake-level records from the same lake. The validation suggests that although $P_{\mathrm{smr}}$ decreases were more gradual than changes recorded by the lake-level record, pollen-based climate reconstructions are recording low-frequency (millennial-scale) changes of past climate, whereas lake-level records reflect high- (centennial-scale) and low-frequency changes in water availability in southern Europe. Our interpretation was made possible by the detailed lake-level change reconstruction that is based on the analysis of multiple cores. Although this procedure may be labour-intensive and needs a high number of ${ }^{14} \mathrm{C}$ datings, it offers the possibility to detect, in combination with pollen records, both high- and low-frequency changes of summer moisture.

\section{Acknowledgements}

Financial support by the Swiss National Science Foundation (SNF) to DC, WF and VV (3100AO-102272), by an SNF Post-doctoral Fellowship (PBBE2-108573) and an AXA Research Fund grant to WF, by the French CNRS (ECLIPSE Program) and by the French ANR (LAMA Project, directed by M. Magny and N. Combourieu-Nebout) are gratefully acknowledged. We are thankful to Wyatt Oswald for comments on an early draft. R. Hoffmann (ETH Zürich) and W. Tanner (University of Bern) led the fieldwork, and F. Oberli prepared pollen samples. 


\section{References}

Allen CD, Breshears DD. 1998. Drought-induced shift of a forest-woodland ecotone: rapid landscape response to climate variation. Proceedings of the National Academy of Sciences of the USA 95: 14839-14842.

Allen R, Siegert MJ, Payne AJ. 2008. Reconstructing glacier-based climates of LGM Europe and Russia. Part 3: Comparison with previous climate reconstructions. Climate of the Past 4: 265-280.

Bartlein PJ, Webb T III, Fleri E. 1984. Holocene climatic change in the northern Midwest: pollenderived estimates. Quaternary Research 22: 361-374.

Bellini C, Mariotti Lippi, Mori M, Secci M, Aranguren B, Perazzi P. 2008. Plant gathering and cultivation in prehistoric Tuscany (Italy). Vegetation History and Archaebotany 17: S103-S112.

Berger A, Loutre MF. 1991. Insolation values for the climate of the last 10 million years. Quaternary Science Reviews 10: 297-317.

Bigler C, Larocque I, Peglar SM, Birks HJB, Hall RI. 2002. Quantitative multiproxy assessment of longterm patterns of Holocene environmental change from a small lake near Abisko, northern Sweden. The Holocene 12: 481-496.

Birks HJB. 1998. Numerical tools in palaeolimnology: progress, potentialities, and problems. Journal of Paleolimnology 20: 307-332.

Birks HJB. 2004. Quantitative palaeoenvironmental reconstructions from Holocene biological data. In Global Change in the Holocene, MackayAW, BattarbeeRW, BirksHJB, OldfieldF (eds). Arnold: London; 107-123.

Briks HJB, Line JM, Juggins S, Stevenson AC, ter Braak CJF. 1990. Diatoms and pH reconstruction. Philosophical Transactions of the Paual Society London B 327: 262-278.

Birks HJB, Seppä H. 2004. Pollen-based reconstructions of late-Quaternary climate in Europe: progress, problems, and pitfalls. Acta Palaeobotanica 44: 317-334.

Birks HJB, Line JM, Juggins S, Stevenson AC, ter Braak CJF. 1990. Diatoms and pH reconstruction. Philosophical Transactions of the Royal Society London B 327: 263-278.

Box EO, Fujiwara K. 2005. Vegetation types and their broad-scale distribution. In Vegetation Ecology, van der MaarelE (ed.). Blackwell: Oxford; 106-128.

Cleveland WS, Devlin SJ. 1988. Locally weighted regression: an approach to regression analysis by local fitting. Journal of the American Statistical Association 83: 596-610.

COHMAP Members. 1988. Climatic changes of the last 18,000 years: observations and model simulations. Science 241: 1043-1052. 
Colombaroli D, Vannière $B$, Chapron E, Magny M, Tinner W. 2008. Fire-vegetation interactions during the Mesolithic-Neolithic transition at Lago dell'Accesa, Tuscany, Italy. The Holocene 18: 679-692.

Colombaroli D, Tinner W, van Leeuwen JFN, Noti R, Vescovi E, Vannière B, Magny $M$, Schmidt R, Bugmann H. 2009. Response of broad-leaved evergreen Mediterranean forest vegetation to fire disturbance during the Holocene: insights from the peri-Adriatic region. Journal of Biogeography 36: 314-326.

Davis BAS, Brewer S, Stevenson AC, Guiot J, data contributors. 2003. The temperature of Europe during the Holocene reconstructed from pollen data. Quaternary Science Review 22: 1701-1716.

Diffenbaugh NS, Sloan LC. 2004. Mid-Holocene orbital forcing of regional-scale climate: a case study of western North America using a high-resolution RCM. Journal of Climate 17: 2927-2937.

Digerfeldt G, Sandgren P, Olsson S. 2007. Reconstruction of Holocene lake-level changes in Lake Xinias, central Greece. The Holocene 17: 361-367.

Donders TH, de Boer HJ, Finsinger W, Grimm EC, Dekker SC, Reichart GJ, Wagner-Cremer F. 2010. Impact of the Atlantic Warm Pool on precipitation and temperature in Florida during North Atlantic cold spells. Climate Dynamics (in press) DOI: .

Drescher-Schneider R, de Beaulieu J-L, Magny M, Walter-Simonnet A-V, Bossuet G, Millet L, Brugiapaglia E, Drescher A. 2007. Vegetation history, climate and human impact over the last 15,000 years at Lago dell'Accesa (Tuscany, central Italy). Vegetation History and Archaeobotany 16: 279299.

Finsinger W, Tinner W, van der Knaap WO, Ammann B. 2006. The expansion of hazel (Corylus avellana L.) in the southern Alps: a key for understanding its early Holocene history in Europe? Quaternary Science Reviews 25: 612-631.

Finsinger W, Heiri O, Valsecchi V, Tinner W, Lotter AF. 2007. Modern pollen assemblages as climate indicators in southern Europe. Global Ecology and Biogeography 16: 567-582.

Finsinger W, Belis CA, Blockley SPE, Eicher U, Leuenberger M, Lotter AF, Ammann B. 2008. Temporal patterns in lacustrine stable isotopes as evidence for climate change during the late glacial in the Southern European Alps. Journal of Paleolimnology 40: 885-895.

Giesecke T, Bjune AE, Chiverrell RC, Seppä H, Ojala AEK, Birks HJB. 2008. Exploring Holocene continentality changes in Fennoscandia using present and past tree distributions. Quaternary Science Reviews 27: 1296-1308.

Givnish TJ. 2002. Adaptive significance of evergreen vs. deciduous leaves: solving the triple paradox. Silva Fennica 36: 703-743.

Guiot J, Harrison S, Prentice IC. 1993. Reconstruction of Holocene precipitation patterns in Europe using pollen and lake-level data. Quaternary Research 40: 139-149. 
Howe S, Webb T III. 1983. Calibrating pollen data in climatic terms: improving the methods. Quaternary Science Reviews 2: 17-51.

Huntley B. 1993. Rapid early-Holocene migration and high abundance of hazel (Corylus avellana L.): alternative hypotheses. In Climate Change and Human Impact on the Landscape, ChambersFM (ed.). Chapman \& Hall: London; 205-215.

Huntley B, Prentice Cl. 1988. July temperatures in Europe from pollen data 6000 years before present. Science 241: 687-690.

Jackson ST, Overpeck JT. 2000. Responses of plant populations and communities to environmental changes of the late Quaternary. Paleobiology 26: 194-220.

Jacobson GL Jr, Bradshaw RHW. 1981. The selection of sites for paleovegetational studies. Quaternary Research 16: 80-96.

Jacques J-MS, Cumming BF, Smol JP. 2008. A pre-European settlement pollen-climate calibration set for Minnesota, USA: developing tools for palaeoclimatic reconstructions. Journal of Biogeography 35: 306-324.

Juggins S. 2003. C2 User guide: software for ecological and palaeoecological data analysis and visualisation. University of Newcastle, Newcastle upon Tyne, UK.

Larocque I, Finsinger W. 2008. Late-glacial chironomid-based temperature reconstructions for Lago Piccolo di Avigliana in the southwestern Alps (Italy). Palaeogeography, Palaeoclimatology, Palaeoecology 257: 207-223.

Lotter AF, Birks HJB, Eicher U, Hofmann W, Schwander J, Wick L. 2000. Younger Dryas and Allerød summer temperatures at Gerzensee (Switzerland) inferred from fossil pollen and cladoceran assemblages. Palaeogeography, Palaeoclimatology, Palaeoecology 159: 349-361.

Magny M. 1998. Reconstruction of Holocene lake-level changes in the Jura (France): methods and results. In Palaeohydrology as Reflected in Lake-Level Changes as Climatic Evidence for Holocene Times, HarrisonSP, FrenzelB, HuckriedU, WeissM (eds). Paläoklimaforschung 25: 67-85.

Magny M. 2006. Holocene fluctuations of lake levels in west-central Europe: methods of reconstruction, regional pattern, palaeoclimatic significance and forcing factors. Encyclopedia of Quaternary Geology 2: 1389-1399.

Magny M, de Beaulieu J-L, Drescher-Schneider R, Vannière B, Walter-Simonnet A-V, Millet L, Bossuet $G$, Peyron O. 2006. Climatic oscillations in central Italy during the Last Glacial-Holocene transition: the record from Lake Accesa. Journal of Quaternary Science 21: 311-320.

Magny M, de Beaulieu J-L, Drescher-Schneider R, Vannière B, Walter-Simonnet A-V, Miras Y, Millet L, Bossuet G, Peyron O, Brugiapaglia E, Leroux A. 2007a. Holocene climate changes in the central 
Mediterranean as recorded by lake-level fluctuations at Lake Accesa (Tuscany, Italy). Quaternary Science Reviews 26: 1736-1758.

Magny M, Vannière B, de Beaulieu J-L, Bégeot C, Heiri O, Millet L, Peyron O, Walter-Simonnet A-V. 2007b. Early-Holocene climatic oscillations recorded by lake-level fluctuations in west-central Europe and in central Italy. Quaternary Science Reviews 26: 1951-1964.

Magny M, Galop D, Bellintani P, Desmet M, Didier J, Haas JN, Martinelli N, Pedrotti A, Scandolari R, Stock A, Vannière B. 2009. Late-Holocene climatic variability south of the Alps as recorded by lakelevel fluctuations at Lake Ledro, Trentino, Italy. The Holocene 19: 575-589.

Malone C. 2003. The Italian Neolithic: a synthesis of research. Journal of World Prehistory 17: 235312.

Matter C. 2005. Seismic to core correlation in the Lago dell'Accesa, Tuscany. Diploma thesis, ETHZ, Zürich.

McDowell N, Pockman WT, Allen CD, Breshears DD, Cobb N, Kolb T, Plaut J, Sperry J, West A, Williams DG, Yepez EA. 2008. Mechanisms of plant survival and mortality during drought: why do some plants survive while others succumb to drought? New Phytologist 178: 719-739.

Noti R, van Leeuwen JFN, Colombaroli D, Vescovi E, Pasta S, La Mantia T, Tinner W. 2009. Mid and late Holocene Vegetation and fire history of Biviere di Gela, a coastal lake in southern Sicily. Vegetation History and Archaebotany 8: 371-387.

Overpeck JT, Webb IT, Prentice IC. 1985. Quantitative interpretation of fossil pollen spectra: dissimilarity coefficients and the method of modern analogs. Quaternary Research 23: 87-108.

Peyron O, Guiot J, Cheddadi R, Tarasov P, Reille M, de Beaulieu J-L, Bottema S, Andrieu V. 1998. Climatic reconstruction in Europe for 18,000 yr B.P. from pollen data. Quaternary Research 49: 183196.

Pignatti S. 1997. Ecologia del Paesaggio. UTET: Torino.

Prentice IC. 1980. Multidimensional scaling as a research tool in quaternary palynology: a review of theory and methods. Review of Palaeobotany and Palynology 31: 71-104.

Prentice IC, Bartlein PJ, Webb T III. 1991. Vegetation and climate change in eastern North America since the last glacial maximum. Ecology 72: 2038-2056.

Reed JM, Stevenson AC, Juggins S. 2001. A multi-proxy record of Holocene climatic change in southwestern Spain: the Laguna de Medina, Cadiz. The Holocene 11: 707-719.

Roberts N. 1998. The Holocene: An Environmental History. Blackwell: Oxford.

Roberts N, Jones MD, Benkaddour A, Eastwood WJ, Filippi ML, Frogley MR, Lamb HF, Leng MJ, Reed JM, Stein M, Stevens L, Valero-Garcés B, Zanchetta G. 2008. Stable isotope records of Late 
Quaternary climate and hydrology from Mediterranean lakes: the ISOMED synthesis. Quaternary Science Reviews 27: 2426-2441.

Seppä H, Bennett KD. 2003. Quaternary pollen analysis: recent progress in palaeoecology and palaeoclimatology. Progress in Physical Geography 27: 548-579.

Seppä H, Birks HJB. 2001. July mean temperature and annual precipitation trends during the Holocene in the Fennoscandian tree-line area: pollen-based climate reconstructions. The Holocene 11: 527-539.

Sugita S. 1994. Pollen representation of vegetation in Quaternary sediments: theory and method in patchy vegetation. Journal of Ecology 82: 881-897.

Sugita S, Gaillard M-J, Broström A. 1999. Landscape openness and pollen records: a simulation approach. The Holocene 9: 409-421.

ter Braak CJF, Smilauer P. 2003. CANOCO Reference Manual and CanoDraw for Windows User's guide: Software for Canonical Community Ordination (version 4.5). Centre for Biometry, Wageningen, Ithaca, NY.

Tinner W, van Leeuwen JFN, Colombaroli D, Vescovi E, van der Knaap WO, Henne PD, Pasta S, D'Angelo S, La Mantia T. 2009. Holocene environmental changes at Gorgo Basso, a Mediterranean coastal lake in southern Sicily, Italy. Quaternary Science Reviews 28: 1498-1510.

Turney CSM, Brown H. 2007. Catastrophic early Holocene sea level rise, human migration and the Neolithic transition in Europe. Quaternary Science Reviews 26: 2036-2041.

Tzedakis PC. 2007. Seven ambiguities in the Mediterranean palaeoenvironmental narrative.

Quaternary Science Reviews 26: 2042-2066.

Tzedakis PC, Frogley MR, Lawson IT, Preece RC, Cacho I, de Abreu L. 2004. Ecological thresholds and patterns of millennial-scale climate variability: the response of vegetation in Greece during the last glacial. Geology 32: 109-112.

Vannière B, Colombaroli D, Chapron E, Leroux A, Tinner W, Magny M. 2008. Climate versus humandriven fire regimes in Mediterranean landscapes: the Holocene record of Lago dell'Accesa (Tuscany, Italy). Quaternary Science Reviews 27: 1181-1196.

Verburg PH, Eickhout B, Meijl H. 2008. A multi-scale, multi-model approach for analyzing the future dynamics of European land use. Annals of Regional Science 42: 57-77.

Webb T III. 1986. Is vegetation in equilibrium with climate? How to interpret late-Quaternary pollen data. Vegetatio 67: 75-91.

Wiersma AP, Renssen H. 2006. Model-data comparison for the $8.2 \mathrm{ka} \mathrm{BP}$ event: confirmation of a forcing mechanism by catastrophic drainage of Laurentide Lakes. Quaternary Science Reviews 25: $63-88$. 
Zanchetta G, Drysdale RN, Hellstrom JC, Fallick AE, Isola I, Gagan MK, Pareschi MT. 2007. Enhanced rainfall in the Western Mediterranean during deposition of sapropel S1: stalagmite evidence from Corchia cave (central Italy). Quaternary Science Reviews 26: 279-286. 

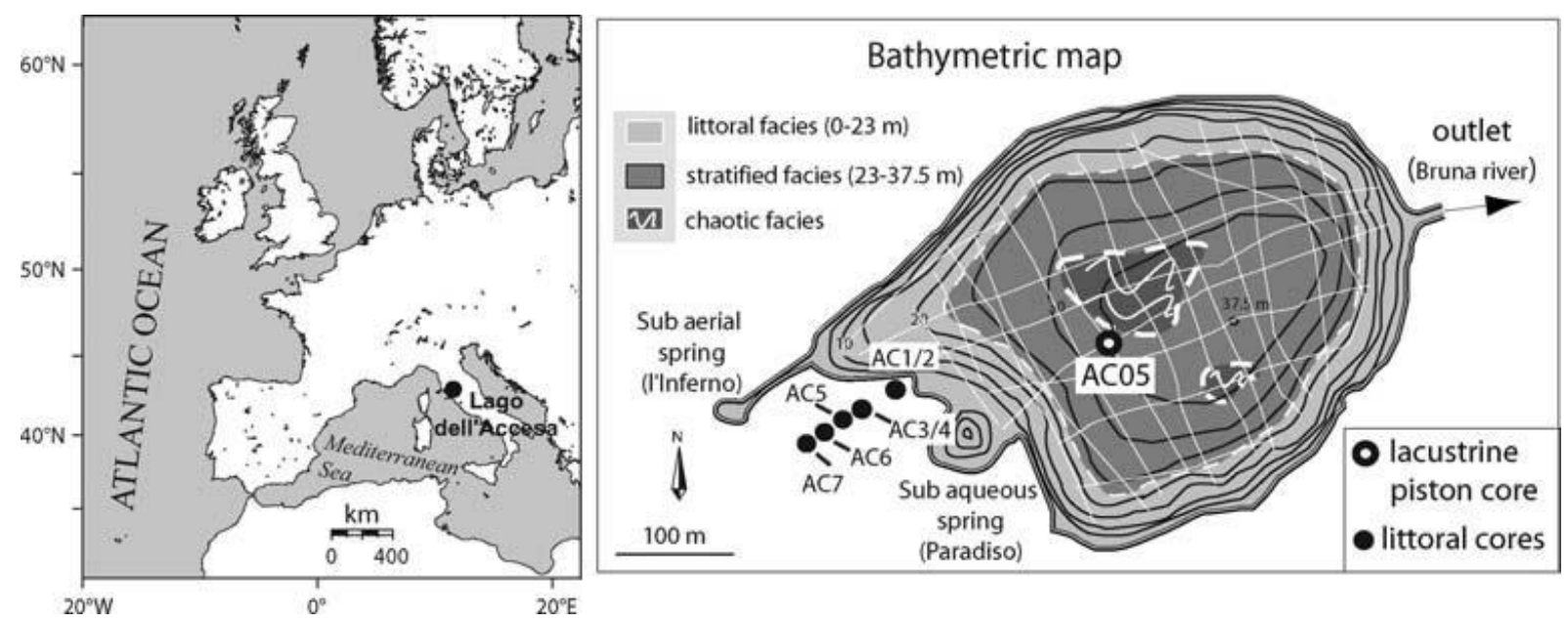

Figure 1 Location of Lago dell'Accesa (left) and sketch map of the lake bathymetry (right) with coring locations (littoral cores AC1/2, AC3/4, AC5,AC6, AC7, and lacustrine core AC05). White lines: grid of high-resolution seismic profiles (modified from Vannie`re et al., 2008) 


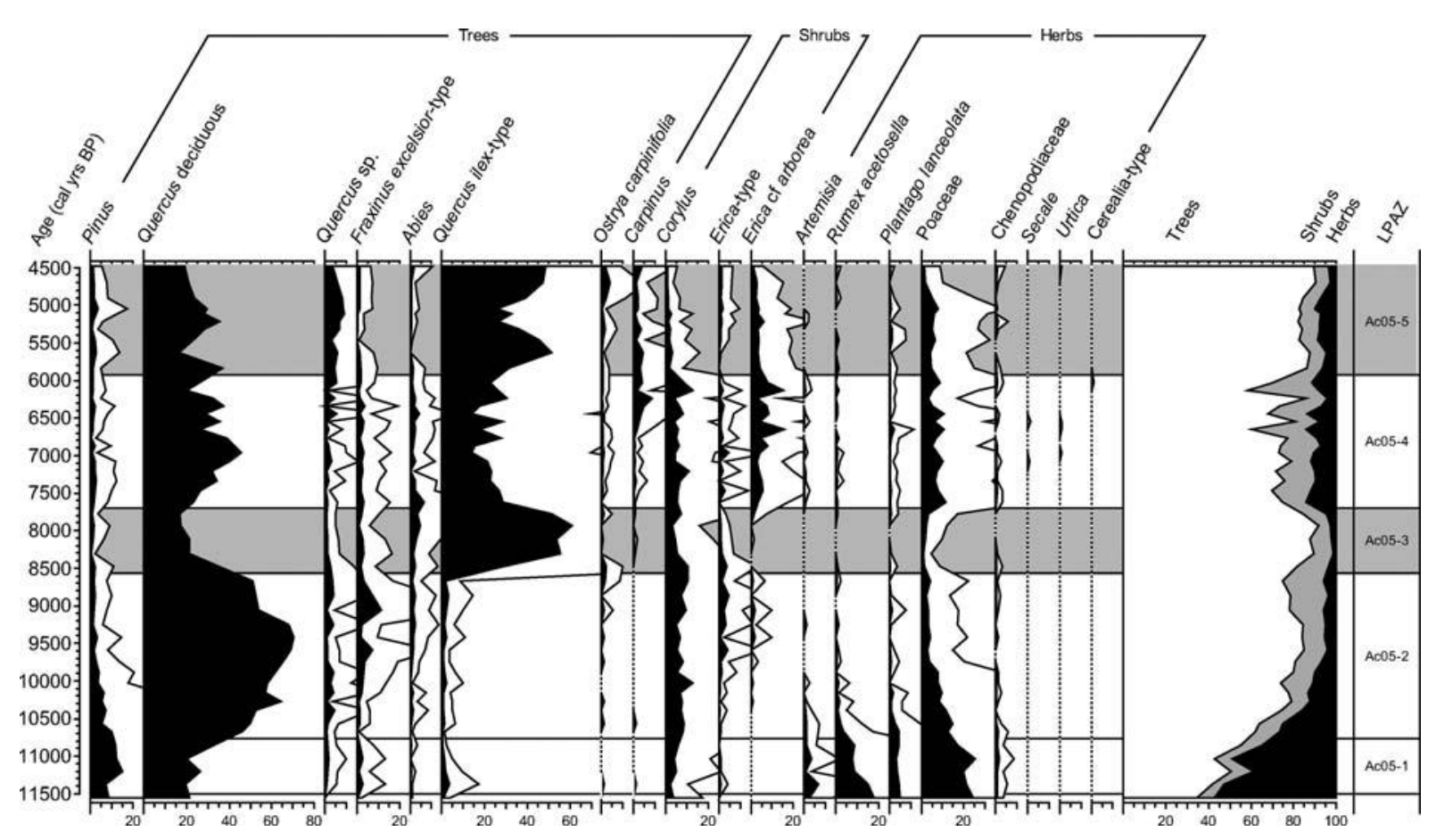

Figure 2 Pollen percentage diagram vs. age (cal. a BP) from Lago dell'Accesa (core AC05, selected taxa only, redrawn from Colombaroli et al., 2008b). Horizontal lines: statistically significant local pollen assemblage zone (LPAZ) boundaries (following Colombaroli et al., 2008b). Grey shaded areas: phases of Q. ilex dominance 

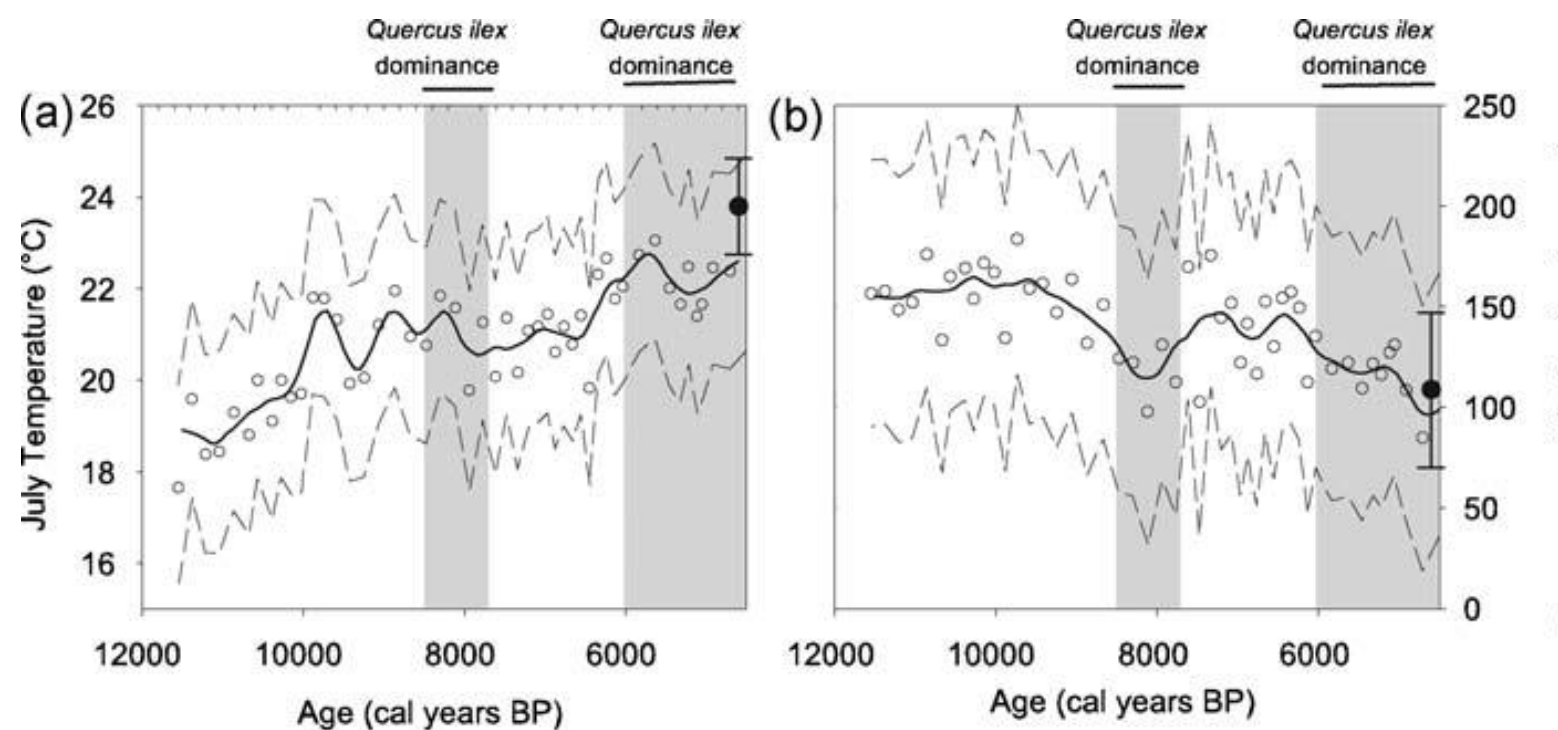

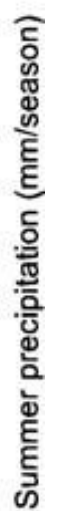
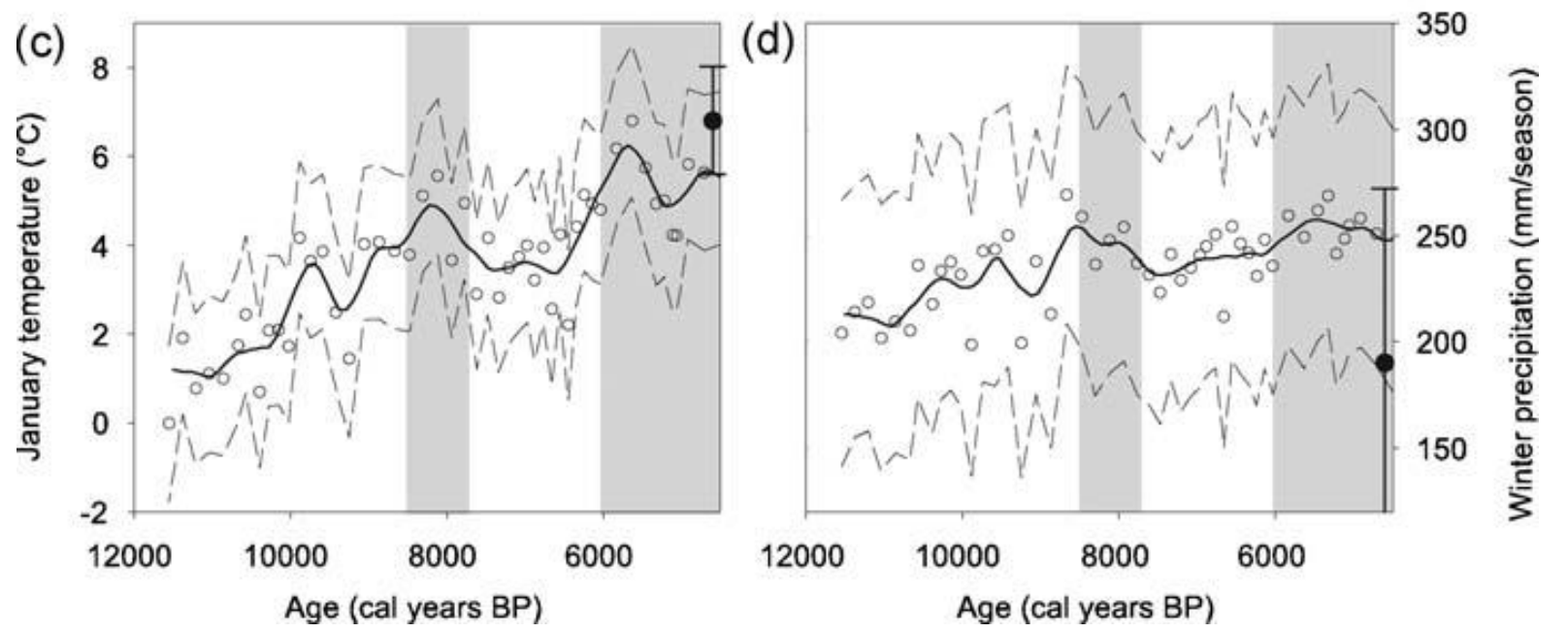

Figure 3 Pollen-inferred climate reconstructions for Lago dell'Accesa: (a) July air temperature; (b) summer precipitation; (c) January air temperature; and (d) winter precipitation. Grey shaded areas: phases of Q. ilex dominance (see Fig. 2). Black lines: loess smoothed record; dashed lines: estimated standard errors of prediction (eSEP); empty circles: pollen-inferred climate estimates; black dots: modern climate data (vertical whiskers: standard deviation of modern climate variable; see Finsinger et al., 2007) 
(A)

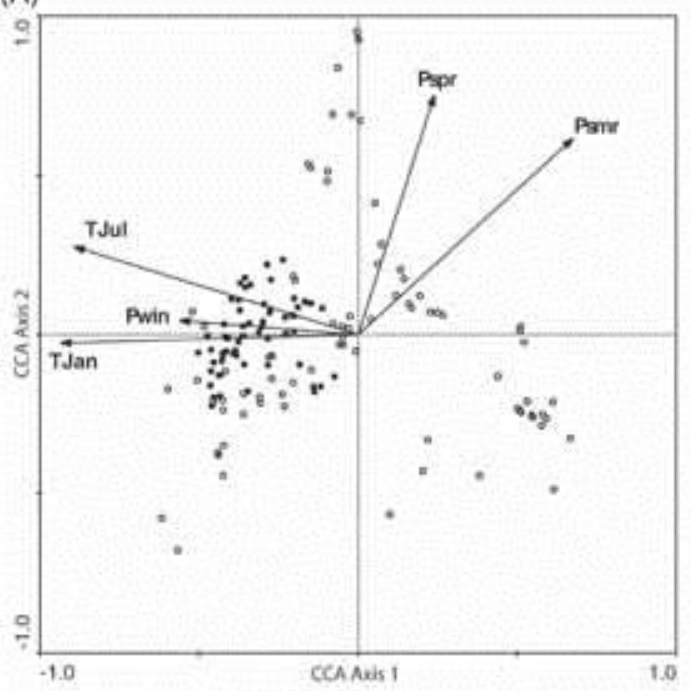

(B)

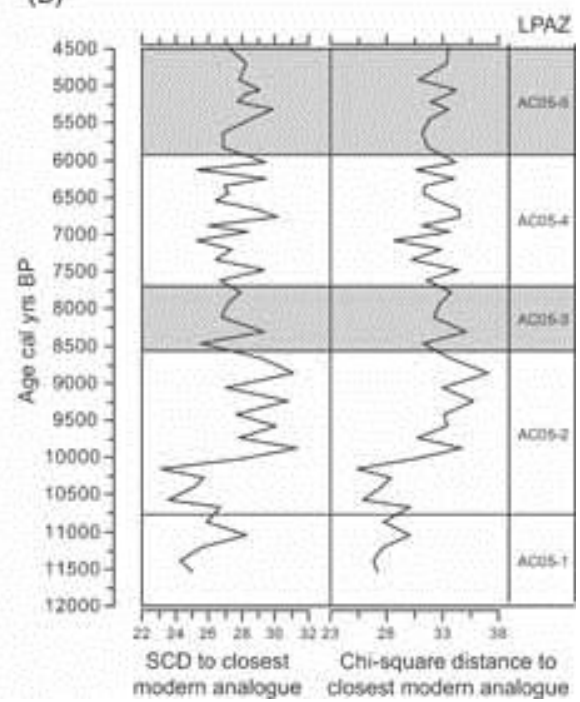

Figure 4. Indirect evaluation of pollen-inferred climate reconstruction at Lago dell'Accesa. (A) CCA analysis with selected environmental variables (arrows), all modern training set pollen assemblages (empty circles), and with the fossil pollen assemblages (black squares) added passively into the ordination. The first CCA axis separates sites with high $T_{\text {Jul }}, T_{\text {Jan }}$ and $P_{\text {win }}$ from sites in the Alpine region (lower $T_{\mathrm{Jul}}$ and $T_{\mathrm{Jan}}$ ) and is significantly stronger than the second axis $\left(\lambda_{1}=0.19, \lambda_{2}=0.09\right)$. (B) Squared-chord distance (SCD) and chi-square distance $(\times 10)$ from fossil samples to closest modern analogue in the training set plotted against age; LPAZs as in Figure 2 


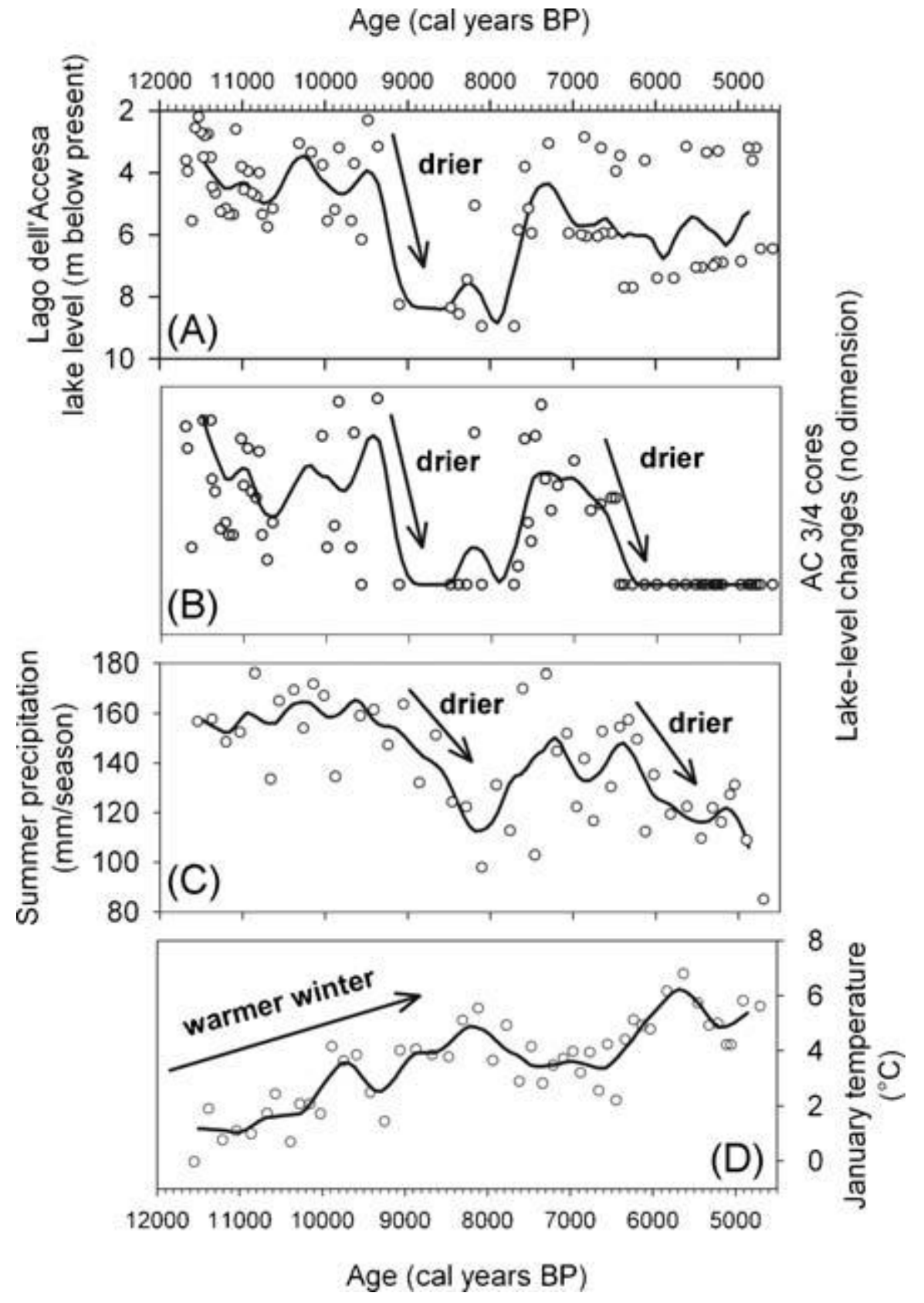

Figure 5 Comparison of the pollen-inferred reconstructions (this study) with lake-level change records at Lago dell'Accesa (from Magny et al., 2007a). (A) Synthesis lake-level change record from cores $A C 3 / 4, A C 5, A C 6$, and $A C 7$. (B) Lake-level change record of cores $A C$ 3/4. (C) Pollen-inferred summer precipitation (Psmr). (D) Pollen-inferred January temperature (TJan). Black lines: loess smoothed records (span $1 / 40.1$, corresponding to a ca. $700 \mathrm{a}$ smoothing window); empty circles: unsmoothed records 